Centaurea Sect. Cyanus: Nuclear Phylogeny, Biogeography, and Life-Form Evolution Author(s): Igor Boršić, Alfonso Susanna, Svetlana Bancheva, Núria Garcia-Jacas

Source: International Journal of Plant Sciences, Vol. 172, No. 2 (February 2011), pp. 238-249

Published by: The University of Chicago Press

Stable URL: http://www.jstor.org/stable/10.1086/657645

Accessed: $17 / 02 / 201102: 51$

Your use of the JSTOR archive indicates your acceptance of JSTOR's Terms and Conditions of Use, available at http://www.jstor.org/page/info/about/policies/terms.jsp. JSTOR's Terms and Conditions of Use provides, in part, that unless you have obtained prior permission, you may not download an entire issue of a journal or multiple copies of articles, and you may use content in the JSTOR archive only for your personal, non-commercial use.

Please contact the publisher regarding any further use of this work. Publisher contact information may be obtained at http://www.jstor.org/action/showPublisher?publisherCode=ucpress.

Each copy of any part of a JSTOR transmission must contain the same copyright notice that appears on the screen or printed page of such transmission.

JSTOR is a not-for-profit service that helps scholars, researchers, and students discover, use, and build upon a wide range of content in a trusted digital archive. We use information technology and tools to increase productivity and facilitate new forms of scholarship. For more information about JSTOR, please contact support@jstor.org. 
Int. J. Plant Sci. 172(2):238-249. 2011.

(c) 2011 by The University of Chicago. All rights reserved.

1058-5893/2011/17202-0008\$15.00 DOI: $10.1086 / 657645$

\title{
CENTAUREA SECT. CYANUS: NUCLEAR PHYLOGENY, BIOGEOGRAPHY, AND LIFE-FORM EVOLUTION
}

\author{
Igor Boršić, ${ }^{* \prime}$ † Alfonso Susanna, ${ }^{1} \dagger$ Svetlana Bancheva, $\neq$ and Núria Garcia-Jacas† \\ *State Institute for Nature Protection, Trg Mažuranića 5, 10000 Zagreb, Croatia; †Botanic Institute of Barcelona \\ (Consejo Superior de Investigaciones Científicas-Institut de Cultura de Barcelona), Passeig del Migdia s/n, \\ Parc de Montjuïc, 08038 Barcelona, Spain; and łInstitute of Botany, Bulgarian Academy of Sciences, \\ Academician Georgi Bonchev Street, block 23, 1113 Sofia, Bulgaria
}

\begin{abstract}
Section Cyanus of Centaurea is a group that is very well defined morphologically and, thus, is a good representative of many radiations of eastern groups of the genus in the Mediterranean region. To confirm the existence of the two natural groups, subsect. Cyanus (annual species) and subsect. Perennes (perennial taxa), typically defined within this section, and to confirm their radiation patterns, a molecular phylogenetic analysis was carried out using the highly variable nuclear-ribosomal spacers ITS (internal transcribed spacer) and 3'ETS (external transcribed spacer). Our results confirm the eastern origin of the group, which probably arose from a Caucasian and North Iranian stock. Both subsections are monophyletic, and annuals (subsect. Cyanus) arose from perennials in Anatolia. The radiations of the two subsections follow very different patterns. Inconsistencies between present classifications and molecular results strongly suggest that the present delineation of some species (Centaurea triumfetti being the best example) is incorrect, and a deep taxonomic revision is necessary.
\end{abstract}

Keywords: biogeography, Centaurea, Cyanus, ITS, ETS, phylogeny.

\section{Introduction}

The Cyanus group (Compositae, Cardueae-Centaureinae) was first mentioned by Miller (1754) as a genus, Cyanus Mill. The first to consider it a section within the genus Centaurea was de Candolle (1838), and this was widely accepted by most subsequent synantherologists (Bentham 1873; Boissier 1875; Hoffmann 1894; Stefanov and Gheorghiev 1931; Dittrich 1968; Wagenitz 1975). Today it is usually recognized as a subgenus (Dostál 1976) or as an informal group within the genus Centaurea (Wagenitz and Hellwig 1996; GarciaJacas et al. 2001). Some authors, however, reassign it to a generic status (Bancheva and Raimondo 2003; Greuter 2003, 2008; Bancheva and Greilhuber 2006). Molecular studies of Centaureinae by Garcia-Jacas et al. (2001) and the tribe Cardueae by Susanna et al. (2006) have shown that the Cyanus and Jacea groups constitute one natural group, with the Cyanus group being sister to the Jacea group. In light of the molecular evidence, the latest compilations of the Cardueae (Susanna and Garcia-Jacas 2007, 2009) suggest that Cyanus should be left within Centaurea.

In contrast with the somewhat controversial taxonomical status of the Cyanus group, its delimitation has never posed a major problem. The group itself has many well-defined morphological characteristics, among which the color of the florets was the first to be observed (Miller 1754). The florets are blue or purplish blue (with only a few exceptions of cream- or

${ }^{1}$ Author for correspondence; e-mail: asusanna@ibb.csic.es.

Manuscript received May 2010; revised manuscript received September 2010. pale pink-flowered taxa), which are extremely unusual colors for the subtribe Centaureinae. Dittrich (1968) noticed that the achenes are conspicuously barbate at the margins of the insertion areole. Nevertheless, the structure of the phyllaries is the most unique characteristic. They have pectinate-ciliate, spineless appendages that are decurrent nearly to the base of the phyllary (Wagenitz and Hellwig 1996). Finally, there are features in this group that are shared with the Jacea and Acrocentron groups. These include the marginal sterile florets without staminodes, the smooth pollen type associated with a reaction pollen presentation mechanism, and the lateral hilum of the seed (Garcia-Jacas et al. 2001).

In addition to the morphological features, the Cyanus group is also characterized by its pollen types. According to Wagenitz (1955), two out of the eight pollen types present in the genus Centaurea s.l. are confined exclusively to this group, within which two subgroups are defined. One is the subgroup of annual species that have the Cyanus pollen type, and the other group consists of perennials with the Montana pollen type. The accepted names for the two groups are Centaurea sect. Cyanus (Mill.) DC. subsect. Cyanus and Centaurea sect. Cyanus subsect. Perennes Boiss.

These two subgroups are also corroborated by karyological data. Annual species show a complex dysploid chromosome series with base chromosome numbers $\mathrm{x}=8,9,10$ and 12 . Perennials, on the other hand, are far more uniform in their base chromosome numbers, with $\mathrm{x}=10$ or 11 (Wagenitz and Hellwig 1996; Garcia-Jacas et al. 2001).

The Cyanus group is distributed throughout central and southern Europe, North Africa, Asia Minor, and the Caucasus, with some species appearing as far east as Iran and Afghanistan (Wagenitz 1975; Dostál 1976; Czerepanov 2001). The 
subsect. Perennes mainly lies within the mountain areas of southeast Europe, Turkey, and the Caucasus (Meusel and Jäger 1992; Hellwig 2004). The area with the highest number of described species is the Balkans (Dostál 1976; Bancheva and Raimondo 2003), which is where most of the taxonomical issues are concentrated. A synthetic treatment by Dostál (1976) gave most of the small endemics described in the area the subspecies rank. However, this classification is disputed and remains very complicated, especially in the microspecies of the Centaurea triumfetti complex (Olšavská et al. 2009).

The annual species of the group have dual distributions, with two widely dispersed weeds and three narrow endemics. One species, Centaurea cyanus, has dispersed synanthropically as a crop weed associated with cereal cultivation since prehistorical times (Rösch 1998). Centaurea depressa is also widely distributed (southwest and central Asia, Spain, Balkans, and Crimea) and is associated with agriculture. Three other species (Centaurea cyanoides, Centaurea pinardii, and Centaurea tchihatcheffii) are distributed within a much narrower area centered in southwest Asia. This subsection does not present any systematic problems, as the only doubtful assignation is associated with one of the Anatolian endemics, Centaurea tchihatcheffii. Because of some of its unusual and unique characteristics, such as its funnel-shaped marginal flowers with crenate margins and anther tubes with glands at the tip of appendages, this species was combined with the genus Melanoloma Cass. (now a section of Centaurea) as Melanoloma tchihatcheffii by Boissier (1875). It was included in the Cyanus group by Wagenitz (1975) despite its differences.

To date, there has been no extensive molecular investigation of the Cyanus group. However, some representative species were included in wider and more general investigations on the subtribe Centaureinae (Garcia-Jacas et al. 2001) and the tribe Cardueae (Susanna et al. 2006). Considering the copious nuclear-ribosomal DNA sequences available for the Centaureinae, we carried out a molecular survey of the group, using the internal transcribed spacer (ITS) region. We also added the same external transcribed spacer (ETS) that has been used in studies on closely related species of Compositae (Baldwin and Markos 1998; Clevinger and Panero 2000; Urbatsch et al. 2003; Suárez-Santiago et al. 2007) with the following aims: (1) to verify the existence of the two subgroups (subsects. Cyanus and Perennes) as defined by life forms, karyology, pollen types, and biogeography; (2) to explore the relationships between both groups and examine molecular data, which may shed light on the geographic origin of the group; and (3) to verify whether molecular data can improve the systematics of the Balkan group of the taxa.

\section{Material and Methods}

\section{Plants}

Sampling of the plant material focused on providing the most comprehensive representation of the Cyanus group. Therefore, representatives of all five annual species (subsect. Cyanus) and 32 taxa (species and subspecies) from the subsect. Perennes were included. Several widely distributed species from both subsections were represented with more than one population from different parts of their distribution areas.
The entire distribution range of the group was covered with special emphasis on southeast Europe and Turkey. The nomenclature of the taxa was mainly adjusted according to Flora Europaea (Dostál 1976) and Flora of Turkey (Wagenitz 1975), with some exceptions (Centaurea lingulata, according to Susanna and Garcia-Jacas 1996; Centaurea pseudoaxillaris and Centaurea tuberosa, according to Bancheva 1999).

Published sequences and new sequences were used in the analysis of the ITS sequences. All of the 3'ETS sequences analyzed were new. The sources for the published sequences, voucher data, and GenBank sequence accession numbers for the newly studied taxa are given in the appendix.

Centaurea scabiosa L. and Centaurea ochrocephala Wagenitz from sect. Acrocentron were chosen as the outgroup species following Garcia-Jacas et al. (2001). Two plastid noncoding regions, the intergenic spacer $y c f 3-\operatorname{trn} S$ and the intron $\operatorname{trn} G$, were also sequenced in several representative taxa; however, the very low number of informative characters led us to abandon this work.

\section{DNA Extraction}

Total genomic DNA was extracted from herbarium material following the procedure described in Doyle and Doyle (1987) and Cullings (1992). The DNA of older herbarium material was extracted using the DNeasy Plant Kit (Qiagen, Valencia, CA) following the manufacturer's protocol. In some cases, the fresh leaves of plants cultivated in the Botanic Institute of Barcelona or silica gel-dried leaves collected in the field were used (appendix).

\section{nrDNA ITS and ETS Regions Amplification Strategies}

Double-stranded DNA of the entire ITS region (ITS1, 5.8S gene, ITS2) was amplified using 1406F (Nickrent et al. 1994) as the forward primer and ITS4 (White et al. 1990) as the reverse primer. Alternatively, if it was not possible to obtain the whole ITS region, the primers ITS1 (White et al. 1990) and 5.811 (Sun et al. 1994) were used to amplify the ITS1 region, and primers 5.812 (Sun et al. 1994) and ITS4 were used for the amplification of the ITS2 region.

PCR conditions included a hot start at $95^{\circ} \mathrm{C}$ for $4 \mathrm{~min}$ and 30 cycles of amplification that were carried out under the following conditions: $94^{\circ} \mathrm{C}$ for $1 \mathrm{~min} 30 \mathrm{~s}, 55^{\circ} \mathrm{C}$ for $2 \mathrm{~min}$, and $72^{\circ} \mathrm{C}$ for $3 \mathrm{~min}$, with an additional extension step of $15 \mathrm{~min}$ at $72^{\circ} \mathrm{C}$. The $3^{\prime}$ portion of the ETS region was amplified using ETS-Car-1 (Kelch and Baldwin 2003) as the forward primer and 18S-ETS (Baldwin and Markos 1998) as the reverse primer. In Centaurea depressa, this combination of primers failed to amplify any products, so ETS1F (Linder et al. 2000) was used as the forward primer and 18S2L (Linder et al. $2000)$ as the reverse primer instead. PCR conditions for this amplification included a hot start at $95^{\circ} \mathrm{C}$ for $5 \mathrm{~min}$ and $30 \mathrm{cy}-$ cles that were carried out under the following conditions: $94^{\circ} \mathrm{C}$ for $45 \mathrm{~s}, 48^{\circ} \mathrm{C}$ for $45 \mathrm{~s}$, and $72^{\circ} \mathrm{C}$ for $40 \mathrm{~s}$, with an additional extension step of $7 \mathrm{~min}$ at $72^{\circ} \mathrm{C}$.

In some taxa, more than one band was produced by the amplification, and some others could not be sequenced directly. PCR products of those taxa were cloned using the TOPO TA Cloning Kit (Invitrogen, Carlsbad, CA) following the manu- 
facturer's instructions, except that only one-half of the reagents were used. When possible, eight positive colonies from each reaction were screened with direct PCR using the T7 and M13R universal primers following the protocol described by Vilatersana et al. (2007). Five to eight PCR products were selected for sequencing in both directions using the same primers.

\section{nrDNA Sequencing Strategies}

PCR products were purified with the QIAquick PCR Purification Kit (Qiagen) and sequenced with the same primers used in the amplification. Direct sequencing of the amplified DNA segments was performed using the BigDye Terminator Cycle Sequencing v3.1 (Applied Biosystems, Foster City, CA), according to the protocol recommended by the manufacturer. The nucleotide sequencing was performed at the Serveis CientificoTècnics at the University of Barcelona on an ABI PRISM 3700 DNA Analyzer (Applied Biosystems).

\section{Phylogenetic Analysis}

Nucleotide sequences were edited using BioEdit 7.0.1 (Hall 1999) and aligned visually by sequential pairwise comparison (Swofford and Olsen 1990). For the clones, the sequences with unique substitutions in single clones were excluded. Consensus sequences were generated for each of the cloned species, condensing the single base pair differences among clones. This reduced the size of the matrices and the impact of any potential PCR artifacts (chimeric sequences and Taq errors; Cline et al. 1996; Popp and Oxelman 2001). Matrices of obtained data are available on request from A. Susanna.

Two different phylogenetic analyses were performed: maximum parsimony, as implemented in PAUP 4.0b10 (Swofford 2002), and Bayesian inference (BI), using MrBayes 3.1.2 (Huelsenbeck and Ronquist 2001; Ronquist and Huelsenbeck 2003). Separate analyses were conducted on the ITS and the 3'ETS sequence data.

The maximum parsimony analysis involved heuristic searches using tree bisection-reconnection (TBR) branch swapping with character states specified as unordered and unweighted. The indels were treated as missing data. All most-parsimonious trees (MPTs) were saved. To locate islands of MPTs (Maddison 1991), 1000 replications were performed with random taxon addition and TBR branch swapping. Bootstrap support (BS) was estimated (Felsenstein 1985) with 100 replicates, simple taxon addition, and TBR branch swapping.

To determine the best-fit model of molecular evolution for Bayesian inference, the ITS and the 3'ETS matrices were analyzed using hierarchical likelihood ratio tests and Akaike Information Criteria, as implemented in MrModeltest 2.2b (Nylander 2004), which considers only those nucleotide substitution models that are currently implemented in PAUP and MrBayes 3.1.2 (Huelsenbeck and Ronquist 2001; Ronquist and Huelsenbeck 2003). In both cases, each criterion selected different evolutionary models under which BI analyses were then performed. They were initiated with random starting trees and run for $1 \times 10^{6}$ generations. Four Metropolis-coupled Monte Carlo Markov chains were sampled every 100 genera- tions, resulting in 10,000 sample trees. A critical aspect of the Bayesian analysis is to ensure that the Markov chain has reached stationarity. Because all sample points before stationarity are essentially random and usually do not contain useful parameter estimates, 1000 sample trees were discarded as "burn-ins." Internodes with posterior probabilities of at least 95\% were considered to be statistically significant. Trees obtained using different evolutionary models were very similar in their topology, but the general time reversible model (Rodríguez et al. 1990) model, which was common to both analyses, showed slightly higher values of clade support.

The nrDNA ITS and 3'ETS data sets were tested for congruence using the incongruence length difference (ILD) test (Farris et al. 1995a, 1995b), as implemented in WinClada 1.00.08 (Nixon 2002). It was conducted with 10,000 replicates and 10 random addition sequences per replicate, holding two trees at each step and saving two trees perreplicate.

\section{Results}

The numerical results of the analyses of the ITS and 3'ETS data sets are summarized in table 1 . The ITS alignment of the 74 taxa consisted of 478 positions and contained 125 phylogentically informative substitutions. Mean pairwise distances (as calculated by PAUP) within the ingroup varied from $0 \%$ (between 30 pairs of taxa of the Cyanus group of Centaurea) to $9.82 \%$ (between Centaurea tchihatcheffii and Centaurea triumfetti subsp. stricta). Pairwise distances between the ingroup and outgroup varied from $5.12 \%$ (between Centaurea scabiosa and Centaurea epirota population 2) to $10.26 \%$ (between Centaurea ochrocephala and Centaurea cf. triumfetti subsp. adscendens).

The 3'ETS alignment of the 47 taxa consisted of 668 positions and contained 144 phylogentically informative substitutions. Mean pairwise distances (as calculated by PAUP) within the ingroup varied from $0 \%$ (between eight pairs of taxa of the Cyanus group of Centaurea) to $23.88 \%$ (between Centaurea depressa population 3 and Centaurea pinardii). Pairwise

Table 1

Comparison of Results Obtained from the Internal Transcribed Spacer (ITS) and 3' External Transcribed Spacer (ETS) Data Sets

\begin{tabular}{lll}
\hline Data set & \multicolumn{1}{c}{ ITS } & \multicolumn{1}{c}{$3^{\prime}$ ETS } \\
\hline No. taxa & 74 & 47 \\
Total characters & 478 & 668 \\
Informative characters & 125 & 144 \\
No. MPTs & 201,196 & 532,214 \\
No. steps & 264 & 301 \\
Islands & 2 & 4 \\
Consistency index & 0.5451 & 0.5475 \\
Retention index & 0.8056 & 0.7430 \\
Homoplasy index & 0.4549 & 0.4525 \\
Range of divergence, ingroup (\%) & $0-9.82$ & $0-23.88$ \\
Range of divergence, ingroup-outgroup (\%) & $5.12-10.26$ & $9.48-24.66$ \\
\hline
\end{tabular}

Note. The consistency and homoplasy indices are calculated excluding uninformative characters. 
distances between the ingroup and outgroup varied from $9.48 \%$ (between C. ochrocephala and C. epirota population 1) to 24.66\% (between C. scabiosa and C. pinardii).

Only two species were cloned, one for the ITS and another for the ETS region. The first was Centaurea pichleri population 1, in which we found four ITS clones. The second cloned species was Centaurea cf. pindicola, in which we found three ETS clones.

The topology of the trees obtained by parsimony and Bayesian approaches was consistent, although a slightly better resolution was obtained with the Bayesian trees. Therefore, only Bayesian majority-rule consensus trees are shown, with Bayesian posterior probability values (PP) and parsimony BS percentages added onto the branches (figs. 1, 2).

Some noticeable discrepancies were observed in the topologies of the trees obtained from the ITS and 3'ETS regions. The first incongruence was the changing positions of Centaurea triumfetti subsp. lugdunensis and C. triumfetti subsp. aligera. The two species were placed together in the ITS and $3^{\prime}$ ETS analyses, but both the composition of their clade and their positions within the Perennes clade (figs. 1,2) were different. Another inconsistency was the position of C. nigrofimbria, which was placed within the Caucasian and Iranian clade in the ITS analysis (fig. 1) but formed a clade with the Turkish $C$. triumfetti population 1 in the $3^{\prime}$ ETS analysis. Finally, the clade formed by the Iranian and Caucasian representatives was sister to the rest of the Perennes clade in the ITS analysis (fig. 1), a position that was not retained in the 3'ETS tree (fig. 2). Regarding ILD, two different tests were carried out, the first with all the taxa and the second omitting the three species of incongruous position. The data sets were incompatible $(P=0.001$ in both analyses). Considering the differences between the topologies obtained by both data sets and the negative result of the ILD, combining them into a single matrix was not possible.

Trees obtained in both analyses (ITS region, fig. 1; 3'ETS region, fig. 2) showed absolute support for the monophyly of the Cyanus group ( $\mathrm{PP}=1.00, \mathrm{BS}=100 \%)$. In the $3^{\prime} \mathrm{ETS}$ analysis, the Cyanus group was divided into two well-supported clades. The first clade included all of the annual species with strong Bayesian support in the $3^{\prime} \mathrm{ETS}(\mathrm{PP}=1.00, \mathrm{BS}=72 \%$; fig. 2 ), but it was not supported by the Bayesian analysis of the ITS data set $(\mathrm{PP}=0.88$; fig. 1$)$. The second clade encompassed the perennial taxa, within which two clades were formed in the ITS analysis: the first one with the Caucasian and Iranian endemic species and a robust second clade with the rest of the taxa. In both the ITS and 3'ETS analyses, this second clade was a polytomy with several more or less well-supported groups.

The ITS clones 2 and 4 of C. pichleri population 1 were grouped with C. fuscomarginata in a strongly supported clade, but clones 1 and 3 were placed as successive sisters to this clade without support $(\mathrm{BS}<50 \%, \mathrm{PP}=0.63$ and 0.58 , respectively; fig. 1). As for the ETS clones of C. cf. pindicola (fig. 2), one of the clones was grouped with population 2 of $C$. epirota with high support $(\mathrm{PP}=1.00, \mathrm{BS}=82 \%)$, and the other two clones were placed in a polytomy with populations 2,5 , and 6 of Centaurea lingulata; C. fuscomarginata; populations 1, 3, and 4 of C. pichleri; and Centaurea reuterana var. phrygia with high Bayesian support $(\mathrm{PP}=1.00, \mathrm{BS}=73 \%)$.

\section{Discussion}

\section{Taxonomic Implications}

The results of the analyses of the ITS and 3'ETS regions confirm the monophyly of sect. Cyanus. As shown in morphological analyses by Wagenitz and Hellwig (1996) and previous molecular analyses by Garcia-Jacas et al. (2001), two subgroups are defined within sect. Cyanus: annuals and perennials.

Our results point to new evolutionary inferences in the clade of annual species. First, the populations of widespread Centaurea cyanus and Centaurea depressa, associated with agriculture, each form strongly supported clades. In the ITS analysis, the clade formed by the populations of C. cyanus is the sister to the strongly supported clade formed by the rest of annuals. The surprising position of C. cyanus is probably caused by a different mutation rate in the ITS region, which is usually related to differences in the biological history of the species (Smith and Donoghue 2008). In fact, the branches of the annuals are much longer than those of the perennials in both phylograms (figs. 1,2) due to the accumulation of changes, as suggested by Ainouche and Bayer (1999) and Andreasen and Baldwin (2001). However, this general rule is not free of exceptions, depending on the group (Andreasen 2005; Soria-Hernanz et al. 2008). In contrast, the $3^{\prime}$ ETS analysis places C. cyanus well nested in the subsect. Cyanus (fig. 2). Thus, deviating behavior in annuals, when included in molecular analyses, seems to mainly affect the ITS region, as observed in other groups from the subtribe Centaureinae (A. Susanna, M. Galbany, K. Romaschenko, L. Barres, and N. Garcia-Jacas, unpublished manuscript). Finally, all of the analyses have confirmed that Centaurea tchibatcheffii is more closely related to the Cyanus than to the Melanoloma group, which is consistent with the placement by Wagenitz (1975). The ITS results place it as most closely related to the Anatolian group of taxa, including Centaurea pinardii and C. depressa (fig. 1).

It is very difficult to draw taxonomical conclusions from our results about the clade Perennes, other than confirming the need for its taxonomic revision in view of the problems in defining some species. The first of the conflicting species is Centaurea triumfetti, which traditionally has been considered to be a difficult taxon (Wagenitz 1975; Gamal-Eldin and Wagenitz 1991). Populations of alleged C. triumfetti are placed in different clades (figs. 1, 2). Both the ITS and 3'ETS analyses place C. triumfetti subsp. dominii, C. triumfetti subsp. axillaris, and C. triumfetti subsp. pirinensis into one clade, whereas C. triumfetti subsp. triumfetti is positioned in a different clade. These results agree with the morphologically based conclusions of Olšavská et al. (2009). Another example is C. triumfetti subsp. lugdunensis, a subspecies from western Europe that is morphologically very similar to C. triumfetti and is alternately placed in both clades of C. triumfetti (figs. 1, 2). The last important issue regarding the taxonomy of C. triumfetti s.l. is the case of Centaurea lingulata from the Iberian Pensinsula and North Africa, subordinated to C. triumfetti as a subspecies (Dostál 1976). Our results show that the Iberian and North African populations of C. lingulata are more closely related to the eastern Mediterranean stock represented by Centaurea fuscomarginata, Centaurea pichleri, and Centaurea reuterana var. phrygia (fig. 


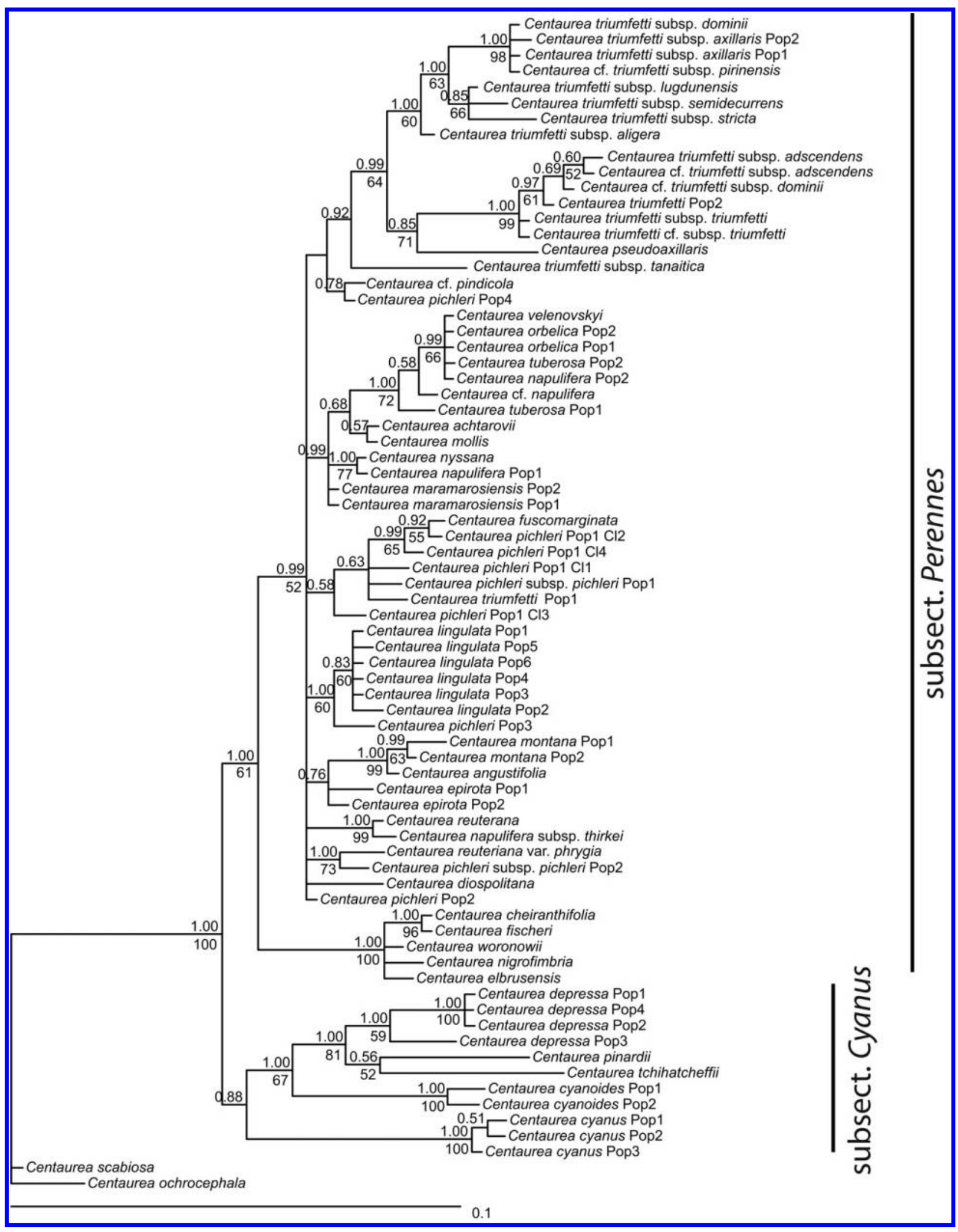

Fig. 1 Majority-rule consensus tree based on Bayesian Monte Carlo Markov chain analysis of internal transcribed spacer region. Numbers above branches are Bayesian posterior probability values; numbers below branches are bootstrap percentages. 


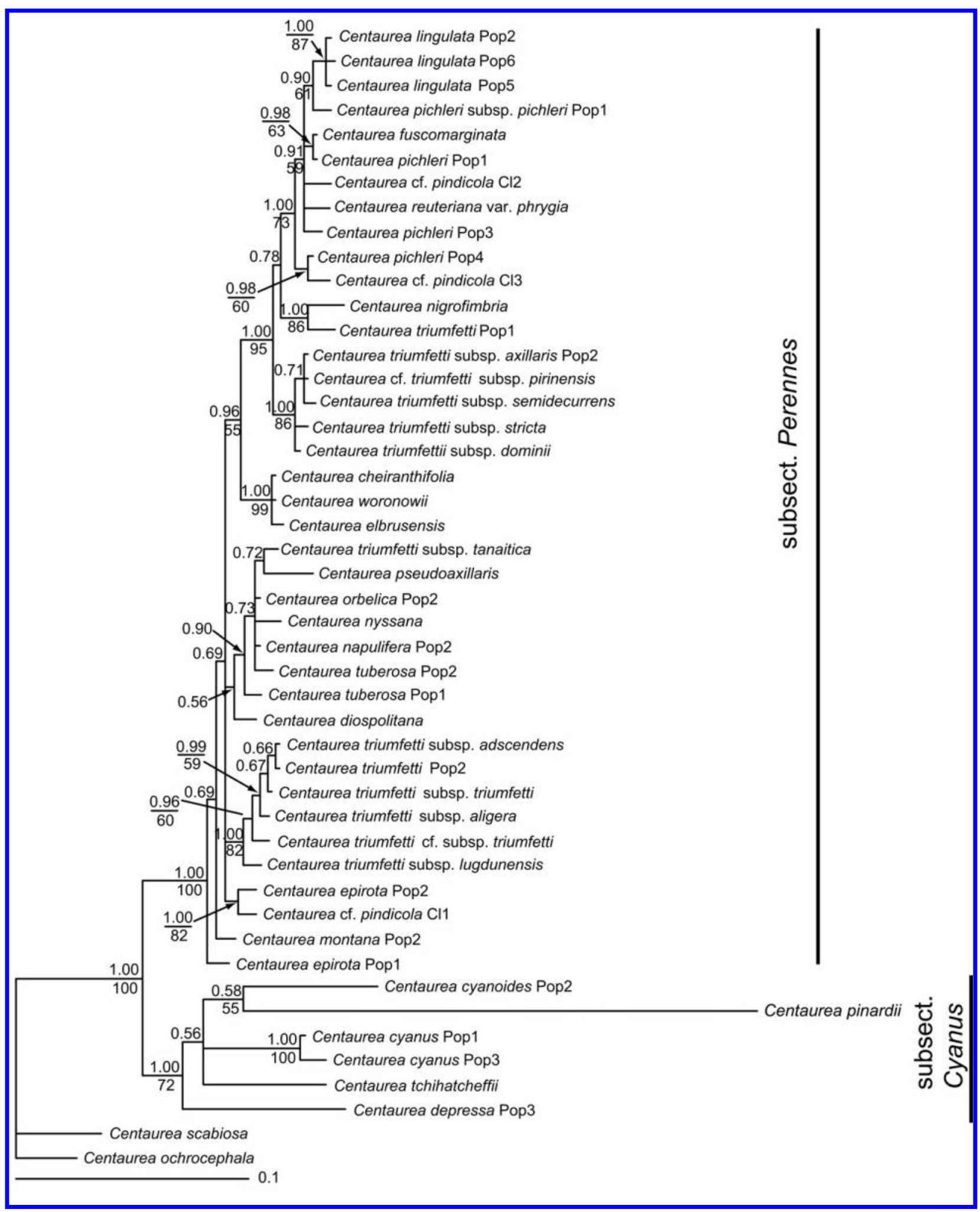

Fig. 2 Majority-rule consensus tree based on Bayesian Monte Carlo Markov chain analysis of 3' external transcribed spacer region. Numbers above branches are Bayesian posterior probability values; numbers below branches are bootstrap percentages. 
2). This result supports the status of C. lingulata as an independent species. A thorough revision of these taxa is highly necessary, and either the delineation or the independence of some species should be questioned.

Another species of controversial delineation is C. pichleri from Greece, Bulgaria, Turkey, and Lebanon. The populations of this taxon included in our study appear to be diversely associated with other eastern taxa and collectively do not form a supported clade in any of our analyses (figs. $1,2)$. Thus, this is another taxon in need of taxonomic revision.

Revision of species boundaries in subsect. Perennes is a very difficult task because of the scarcity of unifying morphological characteristics present (Wagenitz 1975). Most of the current taxonomy of the group is based on vegetative characters such as the presence of sterile rosettes, the presence of taproots or tubers, and the shape and indument of the leaves (Wagenitz 1975; Dostál 1976; Czerepanov 2001). One of these characters, the presence of napiform tubers, is confirmed by our analyses to be a good indicator of phylogenetic affinity. Centaurea napulifera, Centaurea orbelica, Centaurea tuberosa, and Centaurea velenovskyi, which all possess tubers, form a well-supported clade in the ITS analysis (fig. 1). However, other tuberose species like Centaurea diospolitana (Bancheva \& S. Stoyanov) Bancheva, comb. nov. [Basionym Cyanus diospolitanus Bancheva \& S. Stoyanov, Novon (2009) 421], C. napulifera subsp. thirkei, Centaurea nyssana, and Centaurea pseudoaxillaris, which has rudimentary tubers, are not included in this clade. The latter is grouped to another population of C. napulifera that is also placed outside the "tuberose" clade. Finally, it was also suggested by Wagenitz (1980) that Centaurea cheiranthifolia is related to Centaurea elbrusensis, which was corroborated by our findings, suggesting that both of these species belong in the same group.

\section{Introgression and Reticulation}

The difficulties in species delimitation may be caused by a still-incomplete evolutionary differentiation, although they can also be due to hybridization and introgression (Hellwig 2004). The hypothesis of introgression was suggested (Font et al. 2002) and recently confirmed (Garcia-Jacas et al. 2009) for Centaurea sect. Acrocentron. Löser and Hellwig (2007) reported polymorphisms among plastid DNA haplotypes in most populations of perennial species of Cyanus that could also indicate hybridization.

Introgression may also be indicated in the results obtained from Centaurea pindicola. The 3'ETS analysis includes two cloned sequences of this species. One is grouped with Centaurea epirota and the other with C. pichleri (fig. 2). The presence of different copies with different affinities and a lack of congruence between the results of the two data sets strongly suggest introgression, as already noted in C. triumfetti by Wagenitz (1975) and Gamal-Eldin and Wagenitz (1991). The alternative hypothesis for explaining multiple copies would be the presence of pseudogenes or incomplete lineage sorting of ancestral polymorphisms. Pseudogenes and polymorphisms can be ruled out in our case because cloning resulted in well-preserved sequences in both the ITS and ETS regions (Yamaji et al. 2007; Grimm and Denk 2008).

\section{Biogeographic Implications}

Biogeographic implications are also very much of interest. The analysis of the ITS data set defines as the sister to subsect. Perennes the Caucasian and North Iranian representatives of the subsection: C. cheiranthifolia and Centaurea woronowii from Georgia, C. elbrusensis from Iran, Centaurea fischeri from Armenia, and Centaurea nigrofimbria from southeast Russia (fig. 1). Dittrich (1968) reported that C. cheiranthifolia diverged earlier than the other perennial species on the basis of achene characteristics. This group corresponds to the so-called subsect. Fischerianae Czer. (Czerepanov 2001), with the exception of C. nigrofimbria, which was placed into another subsection.

Significantly, a genus from subtribe Centaureinae that has been hypothesized to be related to Centaurea sect. Cyanus on a morphological basis, Psephellus Cass., has a very similar geographic distribution limited to the Caucasus, Anatolia, and northern Iran (Susanna and Garcia-Jacas 2009). The morphological similarities of Psephellus and sect. Cyanus are evident and include an exine ultrastructure, unarmed appendages on the bracts, large and showy sterile peripheral florets, purple or pink corollas, and seeds with lateral hilum (Dittrich 1968; Wagenitz and Hellwig 2000; Susanna and Garcia-Jacas 2009).

The Iberian and North African C. lingulata is more closely related to the eastern Mediterranean stock, as represented by C. fuscomarginata, C. pichleri, and C. reuterana (fig. 2), noted above. In contrast, one species from northern Iberia, C. triumfetti subsp. semidecurrens, is more related to the eastern European stock (figs. 1, 2). These relationships parallel the case of Centaurea sect. Acrocentron (Font et al. 2009), in which two migrations were suggested, one from the south connecting Iberia and North Africa and a second one from central Europe.

\section{Evolution of Life Forms}

Löser et al. (2009) maintained that the perennial taxa are derived from the annuals on the basis of molecular data, morphology, and karyology. Garcia-Jacas et al. (2001) pointed out that the divergence in the annual Cyanus was higher than that of Perennes, which could indicate that Perennes is more recent. We shall review the basis of the hypothesis regarding the evolutionary direction taken by the group.

Morphology alone cannot be used to decide which subsection is ancestral, as reversals and parallel evolution are a constant in the Centaureineae (Garcia-Jacas et al. 2001). Karyology could be a stronger argument, since the annual C. cyanus has the highest basic chromosome number of the Cyanus group $(x=12)$. However, the difference between the Cyanus and Perennes basic chromosome number $(x=12$ and $x=11)$ is minimal, and subsect. Cyanus also has the lowest number of the group $(x=8)$. Finally, our molecular results cannot provide clarification as to which group is older because Cyanus and Perennes are sister clades. Branch lengths in the annuals are longer that in perennials, but whether the differences are due to the varying life histories and habits of these two groups is unknown. Comparisons between groups with different life cycles are risky.

There are arguments to support the hypothesis that the annual species of Cyanus are derived from perennials. First, we can argue against the biogeographic evidence. Perennial taxa 
are, without exception, mesophilous plants growing in the circum-Mediterranean mountains, a conservative habitat where most of the old preglacial flora survived the glaciations (Médail and Diadema 2009). In the Mediterranean region, aridity is a novel condition that arose only in the late Miocene era (Suc 1984). Annual species would have been derived in the east as an adaptation to the increasing aridity, which is consistent with the latest datation of the group that assigned an age of 6-7 million years to Cyanus and Perennes (Barres, personal communication). The geographic distribution of annuals is very suggestive, with their main diversification center in Anatolia. Our results suggest that the perennial species of Cyanus originated in the Caucasus and the adjacent mountains in the extreme north of the Irano-Turanian region (fig. 1), which is consistent with the hypothesis of Psephellus being the most plausible ancestor of the Cyanus group (Susanna and Garcia-Jacas 2009). Annuals probably appeared very soon after in the more arid foothills.

Another argument supporting the idea that annuals are derived from perennials involves pollen type. There is a clear evolutionary line that connects the pollen types Psephellus, Montana, and Cyanus, as reported by Wagenitz (1955), even though this is unsupported by molecular analyses (Susanna and Garcia-Jacas 2009). These three types share identical exine structure (well-conserved endexine in two layers of columellae and smooth ectexine), and differences between them are due only to shape: spherical in Psephellus, prolate in Montana and prolate-laterally compressed in Cyanus ("stadium form"; Wagenitz 1955). In a recent survey of the Centaureinae, Susanna and Garcia-Jacas (2009) correlated the evolution of pollen shape from spherical to prolate with the adaptation to the great oscillations in humidity and temperature typical in arid climates. The laterally compressed Cyanus type would be the ultimate adaptation to the extreme oscillations of temperatures in a Mediterranean climate. From our point of view, the most par- simonious hypothesis would be that the Cyanus pollen type (annual species) evolved from the Montana type of perennials. And, finally, on the basis of the anatomical characteristics of achenes, Dittrich (1968) concluded that perennials were phylogenetically older. We favor the hypothesis that the group evolved from mesophilous-montane perennials (Cyanus subsect. Perennes) to annual species more adapted to the Mediterranean aridity (Cyanus subsect. Cyanus). This would have been through two radical changes: first, the adoption of an annual habit; second, the adaptation of the pollen type to a model more suited for the extreme changes in hygrometry and temperature that are typical of a Mediterranean habitat. More studies within the group are needed to confirm any of the contradicting hypothesis, but difficulties in comparisons between annuals and perennials make molecular methods a less reliable tool.

\section{Acknowledgments}

We thank the curators of the herbaria BC, FI, G, K, LE, SO, SOM, UPA, Z, ZA, ZAHO, and ZT for specimen loan and Olja Vasić for providing C. nyssana material. Igor Boršić thanks all of our friends from the Botanic Institute of Barcelona who helped in many ways during our laboratory work, data analyses, and the preparation of the manuscript. Kostyantyn Romaschenko kindly prepared the GenBank submissions. Financial support from the Spanish Ministry of Education and Science (project CGL2007-60781/BOS) and the Generalitat de Catalunya (Ajuts a Grups de Recerca Consolidats 2009-SGR 439) is gratefully acknowledged. Igor Boršić benefited from a grant from the Ministry of Foreign Affairs and Cooperation and the Spanish Agency of International Cooperation (MAEC-AECI) for the academic year 2006-2007. Suggestions by two anonymous referees and the editor greatly improved the quality of the manuscript.

\section{Appendix}

\section{Voucher Information}

The voucher information includes names of taxa, geographic origin, and collection details of the materials; herbaria where the vouchers are deposited; and GenBank accession numbers (new sequences are underlined). A dash indicates a region that was not sequenced.

Centaurea achtarovii Urum., Bulgaria, Blagoevgrad province: Pirin Mountains, under Vihren Peak, Draževa, 10.8.1973 (SO), HQ147721, HQ147613, -. Centaurea angustifolia Mill., France: Alpes de Savoie, Brezon's pastures, Bourgeau 150, July 1848 (LE), HQ147722, HQ147614, -. Centaurea cheiranthifolia Willd., Georgia, South Ossetia: Ermani, left bank, middle Ermani gorge, $2300 \mathrm{~m}$, Illarionova, 16.7.1958 (LE), HQ147723, HQ147615, HQ147676. Centaurea cyanoides Wahlenb., population 1, Martins and Hellwig 2005, AJ867998, AJ867999, -. Centaurea cyanoides Wahlenb., population 2, Lebanon, Mount Lebanon Governorate: to Ain Aanoub, 715 m, among young wheat, Maitland 391, early May 1959 (LE), HQ147724, HQ147616, HQ147677. Centaurea cyanus L., population 1, USA: Washington, Whitman County, Pullman, Hilltop Stables, Susanna 1450 \& Garcia-Jacas, 5.1993 (WS), HQ147725, HQ147617, HQ147678. Centaurea cyanus L., population 2, France, Lozère: Causse de Sauveterre, cultivated fields between le Sec and l'Aumède, near Chanac, Carretero \& Vilatersana 51, 5.7.1997 (BC), HQ147726, HQ147618, -. Centaurea cyanus L., population 3, Susanna et al. 2006, AY826254, HQ147679. Centaurea depressa M. Bieb., population 1, Iran: Mazandaran, Chalus Road, Azad-bar Mountains between Gachsar and Valiabad, fields, Susanna 1619 et al., 1.8.1996 (BC), HQ147728, HQ147620, -. Centaurea depressa M. Bieb., population 2, Garcia-Jacas et al. 2001, AY012280, AY012316, _. Centaurea depressa M. Bieb., population 3, Armenia: Kamo, near Lake Sevan in Cape Noraduz, $2000 \mathrm{~m}$, margins of cultivated fields, Susanna 1513 et al., 16.8.1995 (BC), HQ147727, HQ147619, HQ147680. Centaurea depressa M. Bieb., population 4, Spain, Toledo: El Emperador (Urda), Garcia-Jacas \& Susanna 2640, 5.6.2006 (BC), HQ147729, HQ147621, -. Centaurea diospolitana (Bancheva \& S. Stoyanov) Bancheva, Bulgaria, Yambol Province: Toundzha hilly country, Lesovo village, $\sim 350 \mathrm{~m}$, Bancheva 0621, 25.05.2006 (SOM), HQ147730, HQ147622, HQ147681. Centaurea elbrusensis Boiss. \& Buhse, Iran: East Azerbaijan (Azarbayjan-e-sharghi), heights of the Sabalan coming 
from Movil, Susanna 1666 et al., 5.8.1996 (BC), HQ147731, HQ147623, HQ147682. Centaurea epirota Halácsy, population 1, Greece: Ioanninon, Pogoniou, Epirus, Mount Dhouskon (Nëmerçka) 3-4 km N of the village Kakolakkos, 1900-2200 m, Hartvig \& Christiansen 7925, det. Landström, 15.7.1979 (UPA), HQ147732, HQ147624, HQ147683. Centaurea epirota Halácsy, population 2, Republic of Macedonia: Prilep District, on stony pasturages on Drenska Mountain, leg. Nikoloff, det. Stojanoff, 23.5 .1918 (SO), HQ147733, HQ147625, HQ147684. Centaurea fischeri Willd., Armenia: Idjevan, north side of Sevan Pass, 1900 m, damp margins of pastures, Susanna 1520 et al., 17.8.1995 (BC), HQ147734, HQ147626, -. Centaurea fuscomarginata (K. Koch) Juz., Ukraine, Crimea: Demerdzhi plateau, Hort \& Burdeynaya, 17.6.1974 (LE), HQ147735, HQ147627, HQ147685. Centaurea lingulata Lag., population 1, Susanna et al. 2006 , AY826258, -. Centaurea lingulata Lag., population 2, Spain, Jaén: Mancha Real, Sierra de Mágina, by the relay station on the Almadén Peak, $\sim 1700 \mathrm{~m}$, bush community on limestone, Susanna 1607 et al., 23.6.1996 (BC), HQ147739, HQ147631, HQ147687. Centaurea lingulata Lag., population 3, Spain, Teruel: Sierra del Pobo, stoneware upper part of TVE relay, lawn, $1700 \mathrm{~m}$, Litzler 72/702 E, 5.7.1972 (ZT), HQ147737, HQ147629, -. Centaurea lingulata Lag., population 4, Spain, La Rioja: Soto en Cameros, Luezas, slopes in regeneration, limestone, $1180 \mathrm{~m}$, UTM 30TWM 4282, Alejandre 1006/88, 5.6.1988. (Z), HQ147736, HQ147628, -. Centaurea lingulataLag., population 5, Morocco, Taza-Al Hoceima-Taounate: Aknoul, Tizi-Ouzli, ascent to Jbel Azrou Akchar, from the mountain pass, $1932 \mathrm{~m}$, Hidalgo \& Romo 13075, 12.6.2005 (BC), HQ147738, HQ̄147630, HQ147686. Centaurea lingulata Lag., population 6, Spain, Madrid: in pastures and grasslands near Cercedilla in Sierra de Guadarrama, granite soil, 1300-1400 m, Vicioso (LE), HQ147740, HQ147632, HQ147688. Centaurea maramarosiensis (Jáv.) Czerep., population 1, Ukraine, Zakarpattia Province: Rakhiv region, Breboia, Yali-

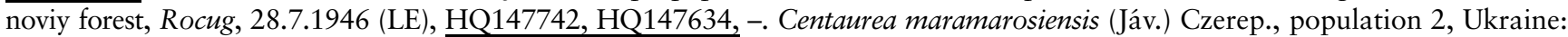
Maramureş, in the upper part of Black Tisza's valley, Margittai, 14.7.1937 (ZT), HQ147741, HQ147633, -. HQ147743,

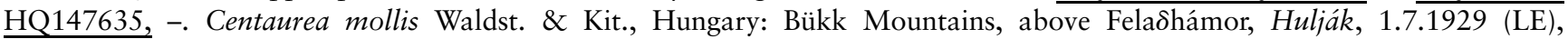
HQ147743, HQ147635, -. Centaurea montana L., population 1, Susanna et al. 2006, L35887, -. Centaurea montana L., population 2, France: Hautes-Alpes, path of Crevasses, mountain pass of Lautaret, Hidalgo 204, 5.7.2007 (BC), HQ147744, HQ147636, HQ147689. Centaurea napulifera Rochel, population 1, Bulgaria, Plovdiv Province: Central Balkan National Park, Central Stara Planina Mountain, rocky meadow near hut "Rai”, Kalofersko, 1950 m, Achtarov, 3.8.1941 (LE), HQ147745, HQ147637, -. Centaurea napulifera Rochel, population 2, Bulgaria: Central Stara Planina Mountain, $\sim 1700 \mathrm{~m}$, leg. Stoyanov, det. Bancheva 03126, 10.07.2003 (SOM), HQ147746, HQ147638, HQ147690. Centaurea cf. napulifera Rochel, Greece: Dramas, Rhodopi Mountains, $\mathrm{N}$ of Zagradenia forest station, area called Trigono near the Bulgarian border, 1800-1850 m, meadow in opening of Picea abies forest, crystalline schist, Strid 19499 et al., 25.7.1981 (G), HQ147747, HQ147639, -. Centaurea napulifera Rochel subsp. thirkei (Sch. Bip.) Dostál, Garcia-Jacas et al. 2006, DQ319136, -. Centaurea nigrofimbria Sosn., Russia: Krasnodarskiy kray region, Krasnaya polyana, Kordon Pslukh, 1600 m, Mishenkova 163, 9.9.1971 (LE), HQ147748, HQ147640, HQ147691. Centaurea nyssana Petrović, Serbia: Suva Mountain, Divna gorica Peak, 1400 m, limestone, Niketić, 13.08.2006 (BEO), HQ147749, HQ147641, HQ147692. Centaurea ochrocephala Wagenitz, Font et al. 2002, FJ459678, FJ459622. Centaurea orbelica Velen., population 1, Republic of Macedonia: Prilep District, at the foot of Pletvar Mountain, leg. Nikoloff, det. Stojanoff, 17.4.1918 (SO), HQ147751, HQ147643, -. Centaurea orbelica Velen., population 2, Bulgaria, Kyustendil Province: Rila Mountain, Suhoto Lake, $\sim 2400 \mathrm{~m}$, Bancheva 0626, 12.06.2006 (SOM), HQ147750, HQ147642, HQ147693. Centaurea pichleri Boiss. subsp. pichleri, population 1, Turkey: Bursa, Uludağ height, $1950 \mathrm{~m}$, steppe, Nydegger 14091, 7.7.1979 (G), HQ147754, HQ147646, HQ147695. Centaurea pichleri Boiss. subsp. pichleri, population 2, Turkey: Kütahya, Kosik Sögüt at Murat Dağ, $1700 \mathrm{~m}$, clearcut with streamlet, Nydegger 44058, 4.6.1989 (G), HQ147755, HQ147647, -. Centaurea pichleri Boiss., population 1, Turkey: Ilgaz Daği Milli Parki, 4004, 208' N, 3243, 850’'E, forest of Abies nordmanniana, Romo 14740 et al., 19.6 .2007 (BC), clone 1, HQ147758, HQ147650, HQ147696; clone 2, HQ147759, HQ147649, HQ147696; clone 3, HQ147756, HQ147651, HQ147696; clone 4, HQ147757, HQ147648, HQ147696. Centaurea pichleri Boiss., population 2, Bulgaria, Smolyan Province: Eastern Rhodope Mountains, between Mandritza village and Likan Cheshma locality, $\sim 700 \mathrm{~m}$, Bancheva 0302, 25.04.2003 (SOM), HQ147752, HQ147644, -. Centaurea pichleri Boiss., population 3, Lebanon, North Governorate: northern Mount Lebanon above Bsharri in cedar forest, $1925 \mathrm{~m}$, Bornmüller 12009 \& Bornmüller, 3.-5.7.1910 (LE), HQ147753, HQ147645, HQ147694. Centaurea pichleri Boiss. population 4, Turkey: between Pinarbasi and Sariz, 38 33 , $458^{\prime} \mathrm{N}, 36^{\circ} 26,705^{\prime} \mathrm{E}, 1781 \mathrm{~m}$, stepic grassland with Juniperus foetidissima, Romo 14864 et al., 23.6 .2007 (BC), HQ147760, HQ147652, HQ147697. Centaurea pinardii Boiss., Garcia-Jacas et al. 2006, DQ319146, HQ147698. Centaurea cf. pindicola Griseb., Greece: E-exposed, rocky steep hillside at hut A, east side of Mount Olympus, 25km SSW from Katerini, 1990-2200 m, leg. Baltisberger \& Meili 11381, det. Wagenitz, 23.6.1987 (ZT), clone 1, HQ147761, HQ147653, HQ147701; clone 2, HQ147761, HQ147653, HQ147699; clone 3, HQ147761, HQ147653, HQ147700. Centaurea pseudoaxillaris Stef. \& Georg., Bulgaria, Sofia Province: in fields at Nova Mahala, leg. Stř́brný, det. Czerepanov, May 1900 (LE), HQ147762, HQ147654, HQ147702. Centaurea reuteriana Boiss., Turkey: Muğla, Sandras Dağ, W side of the summit area, $\overline{37^{\circ} 04^{\prime} \mathrm{N}, 28^{\circ} 50^{\prime} \mathrm{E}, 2100-}$ $2200 \mathrm{~m}$, snowbed meadows and rocky slopes, serpentine, leg. Strid 23345 et al., det. Wagenitz, 7.7.1984 (G), HQ147763, HQ147655, -. Centaurea reuteriana Boiss. var. phrygia Bornm., Turkey: Ala Dağ, track above Demir Kazk, Susanna 2296 et al., 3.8.2002 (BC), HQ147764, HQ147656, HQ147703. Centaurea scabiosa L., Font et al. 2009, FJ459692, FJ459636. Centaurea tchihatcheffii Fisch. \& C. A. Mey., Garcia-Jacas et al. 2006, DQ319170, HQ147704. Centaurea triumfetti All., population 1, Turkey: Balçesme, at the entrance of the village, Susanna 2398 et al., 7.8.2002 (BC), HQ147779, HQ147671, HQ147717. Centaurea triumfetti All., population 2, Slovenia: Primorsko, in meadows near village Senadole at the foot of Vremščica Mountain, $~ 450$ m, Palma \& Trpin, 18.6.1980 (LE), HQ147772, HQ147664, HQ147710. Centaurea triumfetti All. subsp. adscendens Bartl., Croatia, Karlovac county: Klek Mountain, on the upper side opposite to Ogulin, 1100 m, Kárpáti, 16.6.1935 (ZT), HQ147778, 
HQ147670, HQ147716. Centaurea cf. triumfetti All. subsp. adscendens (Bartl.) Dostál, Croatia, Lika-Senj county: on grassy hills at Ljubovo, on Velebit above Halan, Farkaš-Vukotinovič, June-July 1856 (ZA), HQ147769, HQ147661, -. Centaurea triumfetti All. subsp. aligera (Gugler) Dostál, Italy, Lombardy: in shrubs at Mount Lavino, $500 \mathrm{~m}$, Schröter, 27.5 .1886 (ZT), HQ147775, HQ147667, HQ147713. Centaurea triumfetti All. subsp. axillaris (Willd.) Stef. \& T.Georgiev, population 1, Bulgaria, Sofia City: Lozenska Mountain, in oak bushes above village of Pancharevo, Ganchev, 21.5.1953 (SO), HQ147770, HQ147662, -. Centaurea triumfetti All. subsp. axillaris (Willd.) Stef. \& T.Georgiev, population 2, Bulgaria, Sofia Province: Lozenska Mountain, above Dolni Lozen village, $\sim 1000$ m, leg. Stoyanov, det. Bancheva 0715, 24.06 .2007 (SOM), HQ147765, HQ147657, HQ147705. Centaurea triumfetti All. subsp. dominii Dostál, Bulgaria, Plovdiv Province: Trojanska

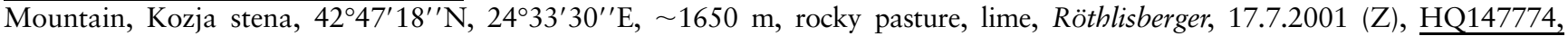
HQ147666, HQ147712. Centaurea cf. triumfetti All. subsp. dominii Dostál, Slovenia: Steinbrück, Faler, 28.5.1908 (ZA), HQ147768, HQ147660, -. Centaurea triumfetti All. subsp. lugdunensis (Jord.) Dostál, France: Department Ain, pass between Bellegarde and Plateau de Retort, $\sim 1130 \mathrm{~m}$ west of the pass, in Narcissus meadows and especially on dry edges, Landolt, 15.6.1991 (ZT), HQ147771, HQ147663, HQ147709. Centaurea cf. triumfetti All. subsp. pirinensis (Degen, Urum. \& J. Wagner) Dostál, Bulgaria, Blagoevgrad Province: Pirin Mountain, stony slopes at the elevated parts of the "Bayuvi Dupli" Natural Reserve, leg. Evstatieva, det. Vichodcevski, 10.7.1968 (SO), HQ147767, HQ147659, HQ147708. Centaurea triumfetti All. subsp. semidecurrens (Jord.) Dostál, Spain, Barcelona: Coll de Montnegre de Ponent (St. Iscle de Vallalta), 720 m, leg. Pannon, det. Vilatersana, June 2000 (BC), HQ147773, HQ147665, HQ147711. Centaurea triumfetti All. subsp. stricta (Waldst. \& Kit.) Dostál, Garcia-Jacas et al. 2006 as C. mollis, DQ319133, HQ147706. Centaurea triumfetti All. subsp. tanaitica (Klokov) Dostál, Ukraine, Luhansk Province: Mt. Bryanka near Zamkovka, Deripova, 1.6.1980 (LE), HQ147766, HQ147658, HQ147707. Centaurea triumfetti All. subsp. triumfetti, Croatia, Split-Dalmatia county: Mosor Mountain, Kotlenice, in the surroundings of village Vladovići, dry grassland and abandoned cultivated areas, Vladović, 19.5.1990 (ZA), HQ147776, HQ147668, HQ147714. Centaurea triumfetti All. cf. subsp. triumfetti, Hungary: Budapest, Sashegy, Wágner, 5.6.1944 (LE), HQ147777, HQ147669, HQ147715. Centaurea tuberosa Vis., population 2, Greece: Dramas, Mount Falakro, along road from Volakas to the ski center, $41^{\circ} 18^{\prime} \mathrm{N}, 2^{\circ} 01^{\prime} \mathrm{E}$, 1000-1100 m, limestone, opening in Fagus forest, leg. Strid 30110 et al., det. Landström, 4.6.1989 (UPA), HQ147780, HQ147672, HQ147718. Centaurea tuberosa Vis., population 1, Croatia, Split-Dalmatia county: Mosor Mountain, Kotlenice, in the surroundings of village Vladovići, abandoned cultivated areas, Vladović, 24.4.1988 (ZA), HQ147781, HQ147673, HQ147719. Centaurea velenovskyi Adamović, Republic of Macedonia: north foothills of Mount Korab, south side of W-foothills of Kula e Ziberit Peak, $\sim 6$ km NNE from Mali i Korabit Peak, S-exposed lawns, 2000-2100 m, Baltisberger 12450 \& Baltisberger, 26.7.1991 (ZT), HQ147782, HQ147674, -. Centaurea woronowii Bornm. ex Sosn., Georgia, Adjara: Zakavkazie, Batum region, Artvish distr., Woronow 6186, 12.7.1911 (LE), HQ147783, HQ147675, HQ147720.

\section{Literature Cited}

$\rightarrow$ Ainouche A-K, RJ Bayer 1999 Phylogenetic relationships in Lupinus (Fabaceae: Papilionoideae) based on internal transcribed spacer sequences (ITS) of nuclear ribosomal DNA. Am J Bot 86:590-607.

$\rightarrow$ Andreasen K 2005 Implications of molecular systematic analyses on the conservation of rare and threatened taxa: contrasting examples from Malvaceae. Conserv Genet 6:399-412.

Andreasen K, BG Baldwin 2001 Unequal evolutionary rates between annual and perennial lineages of checker mallows (Sidalcea, Malvaceae): evidence from 18S-26S rDNA internal and external transcribed spacers. Mol Biol Evol 18:936-944.

$\rightarrow$ Baldwin BG, S Markos 1998 Phylogenetic utility of the external transcribed spacer (ETS) of 18S-26S rDNA: congruence of ETS and ITS trees of Calycadenia (Compositae). Mol Phylogenet Evol 10:449-463.

Bancheva S 1999 Biosystematic study of genus Centaurea L. (sect. Cyanus and Lepteranthus) in Bulgaria. PhD thesis. Department of Botany, Sofia University.

$\rightarrow$ Bancheva S, J Greilhuber 2006 Genome size in Bulgarian Centaurea s.l. (Asteraceae). Plant Syst Evol 257:95-117.

Bancheva S, FM Raimondo 2003 Biosystematic studies of seven Balkan species from genus Cyanus (Compositae). Bocconea 16:507-527.

Bentham G 1873 Compositae. Pages 162-533 in G Bentham, JD Hooker, eds. Genera Plantarum. Vol 2(1). Reeve, London.

Boissier E 1875 Flora orientalis, sive enumeratio plantarum in Oriente a Graecia et Aegypto ad Indiae fines hucusque observatarum. Vol 3. Georg, Genève.

Clevinger JA, JL Panero 2000 Phylogenetic analysis of Silphium and subtribe Engelmanniinae (Asteraceae: Heliantheae) based on ITS and ETS sequence data Am J Bot 87:565-572. $\rightarrow$ Cline J, JC Braman, HH Hogrefe 1996 PCR fidelity of pfu DNA polymerase and other thermostable DNA polymerases. Nucleic Acids Res 24:3546-3551.

$\rightarrow$ Cullings KW 1992 Design and testing of a plant-specific PCR primer for ecological and evolutionary studies. Mol Ecol 1:233-240.

Czerepanov SK 2001 Subgenus Cyanus. Pages 385-415 in EG Bobrov, SK Czerepanov, eds. Flora of the USSR. Vol 28. Compositae, tribes Cynareae and Mutisieae. Smithsonian Institution, Washington, DC.

de Candolle AP 1838 Prodromus systematis naturalis regni vegetabilis. Vol 6. Treuttel \& Würtz, Paris.

Dittrich M 1968 Morphologische Untersuchungen an den Fruchten der Subtribus Cardueae-Centaureinae (Compositae). Willdenowia 5:67-107.

Dostál J 1976 Centaurea L. Pages 254-301 in TG Tutin, VH Heywood, NA Burges, DM Moore, DH Valentine, SM Walters, DA Webb, eds. Flora Europaea. Vol 4. Cambridge University Press, London.

Doyle JJ, JL Doyle 1987 A rapid DNA isolation procedure for small quantities of fresh leaf tissue. Phytochem Bull 19:11-15.

$\rightarrow$ Farris JS, M Källersjö, AG Kluge, C Bult 1995a Constructing a significance test for incongruence. Syst Biol 44:570-572.

$\rightarrow-1995 b$ Testing significance of incongruence. Cladistics 10: 315-319.

$\rightarrow$ Felsenstein J 1985 Confidence limits on phylogenies: an approach using the bootstrap. Evolution 39:783-791.

$\rightarrow$ Font M, N Garcia-Jacas, R Vilatersana, C Roquet, A Susanna 2009 Evolution and biogeography of Centaurea section Acrocentron inferred from nuclear and plastid DNA sequence analyses. Ann Bot 103:985-997. 
$\rightarrow$ Font M, T Garnatje, N Garcia-Jacas, A Susanna 2002 Delineation and phylogeny of Centaurea sect. Acrocentron based on DNA sequences: a restoration of the genus Crocodylium and indirect evidence of introgression. Plant Syst Evol 234:15-26.

Gamal-Eldin E, G Wagenitz 1991 Centaurea L. Pages 488-525 in A Strid, K Tan, eds. Mountain flora of Greece. Vol 2. Edinburgh University Press, Edinburgh.

$\rightarrow$ Garcia-Jacas N, PS Soltis, M Font, DE Soltis, R Vilatersana, A Susanna 2009 The polyploid series of Centaurea toletana: glacial migrations and introgression revealed by nrDNA and cpDNA sequence analyses. Mol Phylogenet Evol 52:377-394.

$\rightarrow$ Garcia-Jacas N, A Susanna, T Garnatje, R Vilatersana 2001 Generic delimitation and phylogeny of the subtribe Centaureinae (Asteraceae): a combined nuclear and chloroplast DNA analysis. Ann Bot 87:503-515.

$\rightarrow$ Greuter W 2003 The Euro+Med treatment of Cardueae (Compositae): generic concepts and required new names. Willdenowia 33:49-61.

- 2008 Med-checklist: a critical inventory of vascular plants of the circum-Mediterranean countries. Vol 2. Dicotyledones (Compositae). Conservatoire Botanique de la Ville de Genève, Geneva.

$\rightarrow$ Grimm GW, T Denk 2008 ITS evolution in Platanus (Platanaceae): homoeologues, pseudogenes and ancient hybridization. Ann Bot 101:403-419.

Hall TA 1999 BioEdit: a user-friendly biological sequence alignment editor and analysis program for Windows 95/98/NT. Nucleic Acids Symp Ser 41:95-98.

Hellwig FH 2004 Centaureinae (Asteraceae) in the Mediterranean: history of ecogeographical radiation. Plant Syst Evol 246:137-162.

Hoffmann O 1894 Compositae. Pages 324-333 in A Engler, K Prantl, eds. Die natürlichen Pflanzenfamilien. Engelmann, Leipzig.

$\rightarrow$ Huelsenbeck JP, F Ronquist 2001 MRBAYES: Bayesian inference of phylogenenetic trees. Bioinformatics 17:754-755.

$\rightarrow$ Kelch DG, BG Baldwin 2003 Phylogeny and ecological radiation of new world thistles (Cirsium, Cardueae-Compositae) based on ITS and ETS rDNA sequence data. Mol Ecol 12:141-151.

$\rightarrow$ Linder CR, LR Goertzen, B Vanden Heuvel, J Francisco-Ortega, RK Jansen 2000 The external transcribed spacer of the rDNA repeat: a new nuclear region for low-level taxonomic analysis of the Asteraceae and closely allied families. Mol Phylogenet Evol 14:285-303.

Löser C, G Akaydin, FH Hellwig 2009 Incomplete lineage sorting among annuals and perennials in the genus Cyanus. Paper presented at Systematics 2009, 7th Biennial Conference of the Systematics Association, Leiden, August 10-14.

Löser C, FH Hellwig 2007 Chloroplast DNA haplotype diversity in Centaurea sect. Cyanus. Paper presented at Botanical Congress 2007, Hamburg, September 3-7. University of Hamburg, Faculty for Mathematics, Informatics and Natural Sciences-Department of Biology.

$\rightarrow$ Maddison DR 1991 The discovery and importance of multiple islands of most-parsimonious trees. Syst Zool 40:315-328.

$\rightarrow$ Martins L, FH Hellwig 2005 Systematic position of the genera Serratula and Klasea within Centaureinae (Cardueae, Asteraceae) inferred from ETS and ITS sequence data and new combinations in Klasea. Taxon 54:632-638.

$\rightarrow$ Médail F, K Diadema 2009 Glacial refugia influence plant diversity patterns in the Mediterranean Basin. J Biogeogr 36:1333-1345.

Meusel H, EJ Jäger 1992 Vergleichende Chorologie der zentraleuropäischen Flora. Vol 3. Fischer, Jena.

Miller P 1754 The gardeners dictionary. Abridged ed. 4. Privately published, London.

$\rightarrow$ Nickrent DL, KP Schuette, EM Starr 1994 A molecular phylogeny of Arceuthobium (Viscaceae) based on nuclear ribosomal DNA internal transcribed spacer sequences. Am J Bot 81:1149-1160.

Nixon KC 2002 WinClada, version 1.00.08. Published by the author, Cornell University. http://www.cladistics.com/.
Nylander JAA 2004 MrModeltest, version 2. Program distributed by the author. Evolutionary Biology Centre, Uppsala University. http:// www.abc.se/ nylander/.

Olšavská K, M Perný, P Mártonfi, I Hodálova 2009 Cyanus triumfetti subsp. triumfetti (Compositae) does not occur in the western Carpathians and adjacent parts of Pannonia: karyological and morphological evidence. Nordic J Bot 27:21-36.

$\rightarrow$ Popp M, B Oxelman 2001 Inferring the history of the polyploid Silene aegaea (Caryophyllaceae) using plastic and homoeologous nuclear DNA sequences. Mol Phylogenet Evol 20:474-481.

$\rightarrow$ Rodríguez F, JL Oliver, A Marín, JR Medina 1990 The general stochastic model of nucleotide substitution. J Theor Biol 142: 485-501.

$\rightarrow$ Ronquist F, JP Huelsenbeck 2003 MRBAYES 3: Bayesian phylogenetic inference under mixed models. Bioinformatics 19:15721574.

$\rightarrow$ Rösch M 1998 The history of crops and crop weeds in southwestern Germany from the Neolithic period to modern times, as shown by archaeobotanical evidence. Veget Hist Archaeobot 7: 109-125.

$\rightarrow$ Smith SA, MJ Donoghue 2008 Rates of molecular evolution are linked to life history in flowering plants. Science 322:86-89.

$\rightarrow$ Soria-Hernanz DF, O Fiz-Palacios, JM Braverman, MB Hamilton 2008 Reconsidering the generation time hypothesis based on nuclear ribosomal ITS sequence comparisons in annual and perennial angiosperms. BMC Evol Biol 8:344.

Stefanov B, T Gheorghiev 1931 Contribution to distinction of the species of genus Centaurea (L.)-sect. Cyanus (DC). Rev Acad Bulg Sci 44:133-193. (In Bulgarian.)

$\rightarrow$ Suárez-Santiago VN, MJ Salinas, N Garcia-Jacas, PS Soltis, DE Soltis, G Blanca 2007 Evolution by reticulation of the Acrolophus subgroup (Centaurea L., Compositae) in the occidental Mediterranean: origin and diversification of the section Willkommia Blanca. Mol Phylogenet Evol 43:156-172.

$\rightarrow$ Suc JP 1984 Origin and evolution of the Mediterranean vegetation and climate in Europe. Nature 307:429-432.

$\rightarrow$ Sun Y, DZ Skinner, GH Liang, SH Hulbert 1994 Phylogenetic analysis of Sorghum and related taxa using internal transcribed specers of nuclear ribosomal DNA. Theor Appl Genet 89:26-32.

Susanna A, N Garcia-Jacas 1996 El zurrón de las Centaureíneas. Fontqueria 44:25-36.

2009 The tribe Cardueae. Pages 293-313 in VA Funk, A Susanna, TF Stuessy, RJ Bayer, eds. Systematics, evolution, and biogeography of the Compositae. IAPT, Vienna.

2007 The tribe Cardueae. Pages 123-146 in J Kadereit, C Jeffrey, eds. Flowering plants: eudicots: Asterales. Vol VIII in K. Kubitzki, ed. The families and genera of vascular plants. Springer, Berlin.

$\rightarrow$ Susanna A, N Garcia-Jacas, O Hidalgo, R. Vilatersana, T Garnatje 2006 The Cardueae (Compositae) revisited: insights from ITS, trnLtrn-F, and matK nuclear and chloroplast DNA analysis. Ann Mo Bot Gard 93:150-171.

Swofford DL 2002 PAUP*. Phylogenetic analysis using parsimony ("and other methods), ver. 4.0b10. Sinauer, Sunderland, MA.

Swofford DL, GJ Olsen 1990 Phylogeny reconstruction. Pages 411501 in D Hillis, C Moritz, eds. Molecular systematics. Sinauer, Sunderland, MA.

$\rightarrow$ Urbatsch LE, RP Roberts, V Karaman 2003 Phylogenetic evaluation of Xylothamia, Gundlachia, and related genera (Asteraceae, Astereae) based on ETS and ITS nrDNA sequence data. Am J Bot 90:634-649.

$\rightarrow$ Vilatersana R, AK Brysting, C Brochmann 2007 Molecular evidence for hybrid origins of the invasive polyploids Carthamus creticus and C. turkestanicus (Cardueae, Asteraceae). Mol Phylogenet Evol 44: 610-621. 
Wagenitz G 1955 Pollenmorphologie und Systematik in der Gattung Centaurea L. s.l. Flora 142:213-279.

1975 Centaurea L. Pages 465-585 in PH Davis, ed. Flora of Turkey. Vol 5. Edinburgh University Press, Edinburgh.

1980 Centaurea. Pages 313-419 in KH Rechinger, ed. Flora Iranica. Akademische, Graz.

Wagenitz G, FH Hellwig 1996 Evolution of characters and phylogeny of the Centaureinae. Pages 491-510 in DJN Hind, HJ Beentje, eds. Compositae: systematics. Proceedings of the International Compositae Conference, Kew, 1994. Vol 1. Compositae: systematics. Royal Botanic Gardens, Kew.
2000 The genus Psephellus Cass. (Compositae, Cardueae) revisited with a broadened concept. Willdenowia 30:29-44.

White TJ, TD Bruns, S Lee, JW Taylor 1990 Amplification and direct sequencing of fungal ribosomal RNA genes for phylogenetics. Pages 315322 in MA Innis, DH Gelfand, JJ Sninsky, TJ White, eds. PCR protocols: a guide to methods and applications. Academic Press, San Diego, CA.

Yamaji H, T Fukuda, J Yokoyama, J-H Pak, C-Z Zhou, C-S Yang, K Kondo, et al 2007 Reticulate evolution and phylogeography in Asarum sect. Asiasarum (Aristolochiaceae) documented in internal transcribed spacer sequences (ITS) of nuclear ribosomal DNA. Mol Phylogenet Evol 44:863-884. 